\title{
The Impact of Culture and Beliefs in Cancer Care: Turkish Experience
}

\author{
Sedat Ozkan* \\ Faculty of Medicine, Department of Psychiatry, University of Istanbul, Istanbul, Turkey \\ *Corresponding author: Sedat Ozkan, Faculty of Medicine, Department of Psychiatry, University of Istanbul, Istanbul, Turkey; E-mail: sedatozkan_klp@yahoo.com \\ Received: March 17, 2021; Accepted: March 25, 2021; Published: March 29, 2021

\begin{abstract}
The perception and the coping mechanism of cancer is directly affected by the cultures, values and belief systems. Turkish culture in this regard is unique, bridging conservative Islamic beliefs with contemporary Western way of thinking. In this study, the changing attitudes towards cancer and the factors pertaining to it in this process has been discussed within the cultural, social and spiritual framework. There used to be a widespread sense of fatalism and silence surrounding cancer. With increasing modernization, migration to cities, educational levels and prosperity, and the growth of Westernization and participatory society, perceptions and responses changed. Cancer is now a disease that is openly discussed. The sense of fatalism is getting less prevalent. Medical and scientific attitudes play a great role in treatment. The family institution also has a clear supportive function. Family, as well as religious attitudes and beliefs, go a long way in preserving hope.
\end{abstract}

Length of life is perceived as more important than quality of life. In treating the disease, curing it comes before aesthetic concerns. The importance of science in the perception of disease has become more prevalent. Fatalistic or religious attitudes do not play much of a role in undermining treatment. Cancer has resulted in a view and understanding that resynthesizes belief, science and human values in Turkish culture.

Keywords: Attitudes, Beliefs, Culture, Faith, Psychooncology, Participatory society, Perception, Traditional, Modernity, Turkish culture

Cancer is a chronic, life-threatening disease that greatly impacts all spheres of life. Cancer patients develop various and differing emotional, mental, and behavioural reactions regarding their illness during diagnosis, treatment, and the palliative period [1]. The experience of cancer cannot be understood independent from the specific culture [2]. Beliefs and values of a society influence perceptions about the meaning of an illness, the types of treatment or remedies that are useful, and the likely outcome. Cross-cultural differences may lead to ethical dilemmas regarding communication, decision-making, treatment choices and end-of-life decisions.

\section{What is Culture?}

Culture is the sum total of the way of living; includes values, beliefs, standards, language, thinking patterns, behavioural norms, communications styles, etc....

Culture influences many different aspects of daily life - including perceptions, emotions, belief systems, and behaviours. It has an important influence on religion, family structure, gender relationships, and social organisation - as well as on diet, dress, body image and perceptions of illness and medical treatment.

The most important issues that dominate cultural variations in symptom presentation, health care seeking behaviour and illness perception are:

- Variations in family systems and structures (e.g. patriarchal families)
- Variations in age and gender role

- Educational factors

- Socio-economic factors

- Environmental factors (rural or urban)

- The meaning and perceived cause of illness [3].

A culture specific understanding and approach is necessary in delivering the optimum psychiatric and physical care [4].

\section{Turkish Culture}

The history of Turks goes back to 20,000 years prior to the advent of Islam. Turkish culture begins in pre-Islamic Central Asia. The Turks, beginning there, spread over an extensive geographical area, to the Caucasus, Anatolia, the Middle East, the Balkans and Central Europe, and established various states and empires. With their acceptance of Islam, a new age began. Modern Turkey is the focal point of this culture. The modernization and Westernization movement that began in the last 150 years of the Ottoman Empire and was institutionalized by Atatürk, the founder of the republic, formed the basis for a new synthesis and prospects for this culture.

Turkish culture is a synthesis having historical depth and geographic expanse. Perhaps, too, it is a new model for the Central Asian Turkic republics, the Caucasus and the Middle East, and some Balcanic countries which share a common culture and civilizational past with the Turks. 
Atatürk said that the basis of the Turkish republic is culture.

"Turkish culture" should be understood to mean the interaction and synthesis of pre-Central Asian Turkish culture with Islam, and the cultures of Anatolia, the Balkans, the Middle East, and the Caucasus, into which they spread, as well as other areas that were part of the Seljuk and Ottoman Empires, and the modern reformism of Atatürk, the founder of modern Turkey. It is a synthesis of conservative, traditional and religious values with modern Western culture. The Sufi movement is a traditional medieval Turkish approach that teaches spirituality through near-mysticism, using song, dance to induce an altered state and closer connection to God. This new attitude towards the mind, freeing mental illness from implications of wrongdoing, paved the way for a more scientific examination of the causes and symptoms of mental illness.

Turkish cultural traditions had developed a humanistic orientation that is concerned with treating the "whole person", thus emphasizing on the integrity of the individual -his mind and body-. Through the centuries, all the "Houses of Healing" established in Turkish world integrated mental and physical health (Gevher Nesibe built in 1200's is the first hospital serving both physically and mentally ill patients [5].

\section{Illness Perception: IPQ-R: Turkish Version}

Turkish version of the illness perception Questionnaire - $\mathrm{R}$ was adapted by [6] and is a reliable and valid tool in using for research studies in cultural aspects of cancer patients.

After the translation and language consistency of the Turkish version, the scale was applied to 203 cancer patients at Istanbul University, Oncology Institute. The study revealed that patients who lack of knowledge and information regarding cancer resulted in fatalistic and passive causal. The IPQ cause scale showed cancer patients to endorse most strongly "stress" or "chance/bad luck" as causes for their Illness, with "accident - injury" being the least favoured attribution. Majority of the participants proposed that "destiny" is the cause of illness in the section of the questionnaire where the perceived cause, is asked. The less educated patients in Turkey attribute their illness more to faith [7].

Erbil et al (1996)'s findings suggest that psychosocial distress is expressed differently in Belgium and Turkey. Turkish patients express their anxiety more with somatic complaints [8]. According to the authors, illness perception, a culture-dependent factor, appears to influence psychological adjustment very differently, a correct perception of illness leading to more anxiety in the Belgian patients compared to the Turkish patients [8]. Similarly [9], analyzed the perceptions, causal attributions, and attitudes toward help of a group of 33 Jewish Israeli cancer patients and found two distinct response patterns-that of the 'Western' patients (science-oriented, active) and that of the 'Oriental' ones (fatalistic, passive).

\section{Special Issues in Communication: Telling the Truth}

Revealing the diagnosis to a patient with terminal cancer is not currently fully accepted in some countries without an Anglo-Saxon cultural background such as Turkey, where there is a family hierarchy and the family of the patient makes the decisions about treatment, physicians discuss the cancer diagnosis with the family before discussing it with the patient and commonly comply with the family members' requests. Similar paternalistic approach is also relevant for Arab and Islamic cultures. There is a tendency to disclose the truth more often than in the past, but full openness is still not a common practice.

Different practices and regulations: due to the current disclosure regulations and patient rights to participate in decision making in Western countries. Western medicine is taught and practised using a model of full disclosure which is considered important for patients to be able to make decisions about their treatment $\mathrm{d}$ to be informed fully prior to giving consent to treatment. At the opposite end of the spectrum is the non-maleficence model, whereby the patient is not told of a poor prognosis in the belief that this will protect him or her against unnecessary physical and emotional harm. Some cultures view discussion of serious illness and death as impolite and provoking unnecessary anxiety, depression, and a sense of helplessness, thereby eliminating all hope.

Somewhere in the middle of the spectrum is the model of beneficence, where family members actively participate in the communication, share the burden of a poor prognosis with the patient, and encourage hope. This is the general attitude in Turkey. In the last two decades, changes in Turkish society has been rapid, complex, and irregular. These changes include growth in population, urbanization, education; which altogether brought a participatory model. The stigma regarding cancer is more prevalent in patients from rural areas and in those who lack necessary knowledge concerning their disease. Studies generally revealed that lack of knowledge and information regarding cancer resulted in fatalistic and passive causal attributions [4]. A study done by [10] revealed that the degree of information and knowledge about one's illness is related with positive problem solving strategies. A silent attitude was the general norm in Turkey. These appear to charge in accordance with changes in the society and culture.

There exist a polar attitude concerning perceptions, causal attributions and attitudes toward cancer: Western style (Science oriented, participating) and eastern style (fatalistic, passive). Our clinical experience and research findings obtained through our liaison psychiatry practice carried out with the breast surgery unit show that in breast cancer patients who had undergone mastectomy, the main basis for distress was the cancer itself, esthetical concerns and effects of cancer to the quality of life was secondary $[11,12]$. Feeling under threat and fear of death and the associated anxiety is prominent, rather than loss reaction associated with breast [4]. Fertility and motherhood are still important for the status of women in rural and more traditional parts of the society. A study by Kulakaç implied that "mother" role of women was considered more basic than female role [13].

Most adult and elderly patients state that their main concern is not facing death but becoming a burden on the family and dying in unbearable pain. Adjustment to cancer is better in a family environment characterized by obsessiveness, open expression of feelings, and absence of family conflict. The most challenging and difficult management issues arise with the loss of child in the family. 
Regarding the effect of cancer on the perception of life [14], reported optimistic findings. In the study, $80 \%$ of the cases reported that cancer had a great impact on their lives, and $48 \%$ evaluated the impact as a positive, life-enhancing experience. Patients reported that experiencing cancer has been a power forcing them to see their lives more positively, giving them a chance to restructure their lives and to change their perspective toward people and the world. The authors reviewed 24 studies on breast cancer published from 1990 to 2010 which revealed a relatively small percentage of women experienced posttraumatic stress disorder, whereas the majority reported posttraumatic growth. Age, education, economic status, subjective appraisal of the threat of the disease, treatment, support from significant others, and positive coping strategies were among the most frequently reported factors associated with these phenomena.

The thesis of [15] was conducted at our department and was titled "Post traumatic growth in cancer patients and related factors." The results revealed a relationship between posttraumatic growth and confrontive coping, self-controlling, accepting responsibility, escape-avoidance, intentional problem solving, positive reappraisal, and seeking social support. The ways of coping and perceptions of illness were important variables affecting posttraumatic growth. Parry and Chesler stated that coping processes and creating meaning and spiritual-moral development are especially associated with long-term psychosocial well-being [16]. The way pain is perceived, manifested and treated by patients and families is another area affected by culture. Cancer patients who are confident in coping and controlling cancer define less pain. In our practice, we see an association between the severity of pain and depression [17-20].

Taking into consideration and integrating our experience at the Department of Psychooncology, Institute of Oncology, University of Istanbul (main pioneering department in the country), the results of nearly 50 master thesis conducted at our department, and the general psychooncology researchers and experiences shared in major scientific meetings in the country, I would like to summarize my thoughts based on the above as follows:

- In the past 40-50 years, prosperity, democratization and participatory culture has expanded in Turkey.

- Urban migration and westernization has contributed to social consciousness.

- Up until the 1970 s and 1980s, cancer was perceived as equivalent to death and was referred to as a "cruel illness" and silent attitude most prevalent.

- Cancer has become less of a taboo subject in Turkish society; there has been increasing awareness regarding cancer in society.

- The discussion of cancer in academia and the media has become increasingly multifaceted.

- The perception of cancer as a catastrophe has declined in society. More emphasis is placed on the importance of psychological and social support.
- Psychooncology practice helped decreasing the prejudice such as only insane people receive treatment from psychiatrists or psychologists. The necessity of psychological support to cancer patients has been readily accepted by the culture.

- The fear of recurrence is still the most prevalent source of anxiety in cancer patients.

- The old-fashioned way of thinking was strongly influenced by religion and arose from within a traditional, feudal social structure. The Westernization occurring and an increasingly institutionalized process of modernization, has given rise to a brand-new structure and way of thinking.

- Religious or spiritual approaches towards illnesses and cancer, with respect to both cause and treatment, have gradually diminished.

- However, the impact of religion on the reactions to cancer can still be seen. A fatalistic approach can be anxiety relieving for some. For others, it can impede treatment. Nevertheless, a fairly widespread and functional way of perceiving and style of coping is characterized by "first do what you can, then leave it to God."

- The approach "if it's cancer, take the entire organ" is common.

- Society and the family still prioritizes longevity over quality of life.

- We see the widespread impact of belief systems pertaining to death and the acceptance of death issues basically.

- In Turkey, when it comes to cancer, religion, strongly tied to a belief in Islam, is associated with a reduction in loss of hope, suicidal thinking and dying in the hospital.

- We see that in the terminal phase, turning toward religion and resorting to prayer increases more.

- Religious thought and rituals are prevalent in the processes of saying goodbye.

- There are conflicting reports on the effects of religion on (better) health.

- In Turkish patients with cancer, it is commonly observed that a diagnosis of cancer makes people more faithful; while they may not practice more.

- There is an increase in perceptions of meaningfulness in life and hope. The perception of "There is always hope with God."

- The association between religion and spirituality and cancer has not been systematically studied in Turkey. We do not know the impact of religion and spirituality on the outcome of cancer.

- With regard to grief, concerns about death and the afterlife, I see that patients and families turn more to religion for guidance, without sacrificing scientific treatments. 
- In Turkish culture, the cancer care is more family oriented than individualistic. In cases that are perceived as catastrophic such as earthquakes, cancer, all the family members get together and face this situation all together. This is generally supportive for the patient. Sometimes it may act as a protective factor.

- In case of grief and bereavement, the experience is lived collectively and more religiously. The grief process is not lived through individualistically and silently as in some Western countries. Wailing and crying outs are more common.

- Religious assessment of cancer patients is not routinely done in clinics in Turkey.

- Religious concerns and needs of patients are not routinely addressed.

- On the other hand, the practice of psychotherapy does not routinely integrate spirituality, unless actively requested by the patient. This area is mostly covered by families.

The integration of traditional values of Turkish culture and modern western values, the impact and continued functionality of the family, a sense of social solidarity, religious beliefs, and a humanistic understanding rooted in culture has given rise to a synthesis of two views: "health is more important than anything else" and "with God there is hope." Our culture has a positive impact on treatment by seeing the patient and his cancer within the framework of a mind-body holism.

\section{References}

1. Ozkan M (2016) Psychosocial Adaptation During and After Breast Cancer. In: A Aydıner, A İğci, A Soran (eds.), Breast Disease: Management and Therapies, Istanbul: Springer International Publishing Switzerland, pp: 821-852.

2. Brown R, Bylund C, Kissane D (2010) Principles of Communication Skills Training in Cancer Care. In: WBJ Holland (eds.), Psycho-Oncology, New York: Oxford University Press, pp: 597-604.

3. Anuk D, Özkan M, Kizir A, Özkan S (2019) The Characteristics and Risk Factors for Common Psychiatric Disorders in Patients with Cancer Seeking Help for Mental Health. BMC Psychiatry pp: 1-11.

4. Özkan S, Özkan M, Armay Z (2011) Cultural Meaning of Cancer Suffering. Pediatr Hematol Oncol pp: 102-104.
5. Özkan S (2007) The Historical Development of Mental Health in Turkish Culture. Gevher Nesibe Hospital and Medical Academy pp: 77-83.

6. Kocaman N, Özkan M, Armay Z, Özkan S (2007) The Reliability and the Validity Study of Turkish Adaptation of the Revised Illness Perception Questionnaire. Anadolu Psikiyatri Dergisi pp: 271-280.

7. Armay Z, Özkan M, Kocaman N, Özkan S (2007) Hastalık Algısı Ölçeği'nin Kanser Hastalarında Türkçe Geçerlilik ve Güvenilirlik Çalıșması. Klinik Psikiyatri pp: 192200 .

8. Erbil P, Razavi D, Farvacques C (1996) Cancer patients psychological adjustment and perception of illness: Cultural differences between Belgium and Turkey. Support Care Cancer pp: 455-461.

9. Baider L, Sarell M (1983) Perceptions and causal attributions of Israeli women with breast cancer concerning their illness: the effect of ethnicity and religiosity. Psychother Psychosom pp: 136-143.

10. Şener Ş, Günel N, Akçalı Z (1999) Meme Kanserinin Ruhsal ve Sosyal Etkileri Üzerine Bir Çalışma. Klinik Psikiyatri Dergisi 2: 254-260.

11. Özkan S, Turgay M (1992) Masektomi Olgularında Psikiyatrik Morbidite Psikososyal Uyum ve Kanser - Organ Kaybı - Psikopatoloji İlișkisi. Nöropsikiyatri Arșivi, pp: 207215

12. Isıkhan V, Güner P, Kömürcü S (2001) The Relationship Between Disease Features and Quality of Life in Patients With Cancer. Cancer Nursing, pp: 490-495.

13. Kulakaç O, Buldukoglu K, Yılmaz M (2006) An Analysis of the Motherhood Concept in Employed Women in South Turkey. Social Behavior Personality, pp: 837-852.

14. Öner H, İmamoğlu O (1994) Meme kanseri olan Türk kadınlarının hastalıklarına ve uyumlarına ilişkin yargılar. Kriz Derg 2: 261-268.

15. Bayraktar S (2008) Kanser hastalarinda travma sonrasi gelisim olgusunun ve etkileyen faktörlerin incelenmesi. İstanbul Üniversitesi Saglık Bilimleri Enstitüsü, Yüksek lisans tezi.

16. Parry C, Chesler M (2005) Thematic Evidence of Psycho-social Thriving in Childhood Cancer Survivors. Qual Health Res, pp: 1055-1073.

17. Özkan S (2010) Psychiatric Aspects of Pain in Cancer Patients. Asian Pacific Journal of Cancer Prevention, pp: 113-116.

18. Fitchett G, Canada A (2010) The Role of Religion / Spirituality in Coping with Cancer: Evidence, Assessment, and Intervention. In: J Holland, W Breitbart, P Jacobsen, M Lederberg, M Loscalzo, R McCorkle (eds.,), Psycho-Oncology, New York: Oxford University Press, pp: 440-446.

19. Lepore S (2001) A Social Cognitive Processing Model of Emotional Adjustment to Cancer. American Psychological Association, pp: 99-116.

20. Uzun Ö, Aslan F, Selimen D (2004) Quality of Life in Women With Breast Cancer in Turkey. J. Nursing Scholarship, pp: 207-214. 